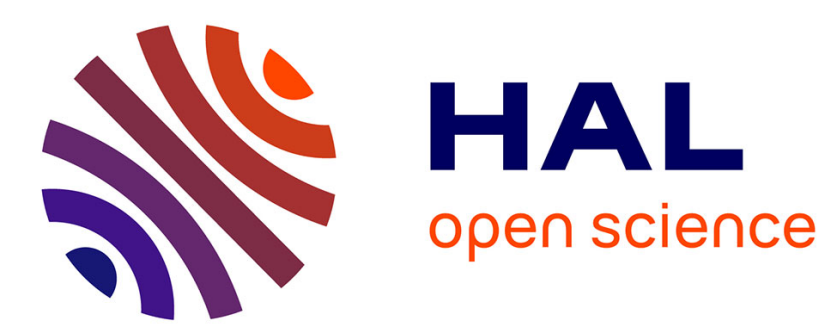

\title{
Pulsed annealing of semiconductors by microwave energy
}

P. Chenevier, J. Cohen, G. Kamarinos

\section{To cite this version:}

P. Chenevier, J. Cohen, G. Kamarinos. Pulsed annealing of semiconductors by microwave energy. Journal de Physique Lettres, 1982, 43 (8), pp.291-294. 10.1051/jphyslet:01982004308029100 . jpa00232048

\section{HAL Id: jpa-00232048 https://hal.science/jpa-00232048}

Submitted on 1 Jan 1982

HAL is a multi-disciplinary open access archive for the deposit and dissemination of scientific research documents, whether they are published or not. The documents may come from teaching and research institutions in France or abroad, or from public or private research centers.
L'archive ouverte pluridisciplinaire HAL, est destinée au dépôt et à la diffusion de documents scientifiques de niveau recherche, publiés ou non, émanant des établissements d'enseignement et de recherche français ou étrangers, des laboratoires publics ou privés. 
Classification

Physics Abstracts

$64.70 \mathrm{~K}-81.10 \mathrm{~J}$

\title{
Pulsed annealing of semiconductors by microwave energy
}

\author{
P. Chenevier, J. Cohen and G. Kamarinos \\ Laboratoire de Physique des Composants à Semiconducteurs $\left({ }^{*}\right)$, \\ ENSERG, 23, rue des Martyrs, 38031 Grenoble Cedex, France
}

(Reçu le 23 novembre 1981, révisé le 4 février 1982, accepté le 23 février 1982)

\begin{abstract}
Résumé. - Une nouvelle méthode de recuit pulsé de semiconducteurs par énergie microonde est proposée et testée. Elle présente un très bon rendement énergétique global ( 20 à $30 \%)$ et elle permet des recuits d'une très bonne homogénéité spatiale des surfaces importantes. Le principe de la méthode ainsi que le montage expérimental relatif aux premiers essais sont décrits. Nous montrons la possibilité de recuire des couches implantées de silicium à condition d'éclairer l'échantillon.

Abstract. - A new method for annealing semiconductors using pulsed microwave power is presented. It has a very good energy efficiency (up to $30 \%$ ), it results in a very good spatial homogeneity of the annealed sample, and important surfaces can be treated at once. The experimental set-up is given. We show the possibility to anneal implanted silicon. For high resistivity samples a simultaneous illumination of the treated surface is needed.
\end{abstract}

1. Introduction. - Several methods of pulsed annealing have been investigated in recent years. These include annealing by laser [1, 2, 3, 4] and by electron beam [5], which were subjected to intensive research. Also investigated, to a lesser degree, were annealing by high intensity arc lamp [6] and, most recently, annealing by thermal radiation [7]. CW laser and electron beam annealing are localized, so that a sweep is necessary to treat large areas. The annealings using large beam laser or large electron beam can treat a relatively large area with wery high power during very brief pulses (a few tens of ns). The other annealing methods mentioned last far longer (a few seconds), but they are capable of treating a large area (in a single pulse).

In this paper, we recommend a new method of pulsed annealing using microwave energy [8]. This method allows annealings of sufficiently short duration (of the order of $100 \mathrm{~ms}$ ) to operate in an ordinary clean room ambience, and to treat relatively large areas. The spatial homogeneity is in principle at least as good as that expected in annealings using a large beam and high peak power pulsed laser (see for example [9]). Moreover, the total energy efficiency is far higher (up to 20 to $30 \%$ ) than with a laser or electron beam. In addition, microwave generators also allow profiling the power pulse, so that the treatment can be accurately controlled.

2. Principle of the method. - The treatment is carried out in a resonant cavity. The sample is located in a zone with homogeneous electric field, and forms the cavity wall locally [8]. At reso-

(*) ERA CNRS 659. 
nance, large currents flow through the sample in a thickness of approximately its skin thickness $\left(10 \mu \mathrm{m}\right.$ at $10 \mathrm{GHz}$ for $\mathrm{Si}$ at $\left.1000^{\circ} \mathrm{C}\right)$. It is in this surface region that the power is dissipated by the Joule effect. Provided that the cavity is of good quality, and that it is at the critical coupling, practically all the energy supplied by the generator is dissipated in the sample.

This operation implies that the surface conductivity of the semiconductor is adequate. While this is true when the sample is at high temperature, it is no longer the case at ambient temperature for implanted silicon samples, for example. To initiate power absorption, free carriers are generated at the surface by illuminating the sample [8]. Note that apart from any considerations concerning the power that the generator can supply, the sample area which can be treated in one pulse is determined by the zone in which the electric field can be considered homogeneous. Hence it depends essentially on the configuration of the cavity.

3. Experimental rig. - We set up an $X$-band experimental test bench (frequency $8.3 \mathrm{GHz}$ ). The generator is an amplifier klystron that can produce up to $8 \mathrm{~kW}$. It delivers rectangular power pulses the rise time of which is negligible in comparison to their duration (50 ms-500 ms). We prepared a cavity of which the central element is a magic $\mathrm{T}$ in guide RG52/U. The generator drives the magic $\mathrm{T}$ by branch (3) of the H-plane T. The sample forms part of the "short-circuit " closing branch (4) of the E-plane T. The sample is a semiconductor strip parallel to the small sides of the guide and along the guide axis (Fig. 1). Tuning adjustement of the cavity and of its coupling coefficient is achieved by moving the mobile short-circuit closing branches 1 and 2 .
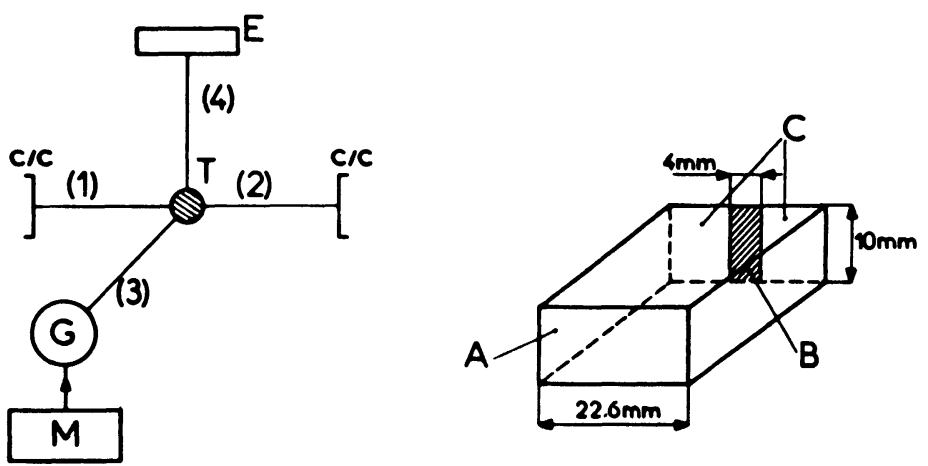

Fig. 1. - Experimental set-up. a) Block-diagram; $\mathrm{G}$ : microwave generator; $\mathrm{M}$ : modulator; $\mathrm{T}$ : magic $\mathrm{T}$; C/C : short-circuit ; E : sample holder. b) Sample holder ; A : guide $X$-band ; B : sample ; C : metallic sheets closing the guide.

The sample is illuminated through a guide at the junction leading to the side of 1-2 opposite branch (4).

In our first tests the sample was fixed as it is shown in detail in figure 2. Besides the illumination was achieved by a simple (General Electric ELH) lamp. The lamp is provided with a large area parabolic reflector $\left(50 \mathrm{~cm}^{2}\right)$ and its electric power equals $300 \mathrm{~W}$. Its colour temperature equals $3350 \mathrm{~K}$ which corresponds to a light spectrum aroung a peak wavelength $\lambda \simeq 1.5 \mu \mathrm{m}$. The lamp is fixed outside the resonant cavity at a distance of $5 \mathrm{~cm}$ from the semiconductor sample. A small part of the emitted light enters the cavity through a rectangular quartz window. The light power reaching the surface of the sample is estimated of the order of $3 \mathrm{~W}$. It is reasonable to assume that the used illumination does not have an important thermal effect on the sample. Indeed our observations and some approximate calculations show that the above described illumination cannot raise the sample temperature above $300{ }^{\circ} \mathrm{C}$. 


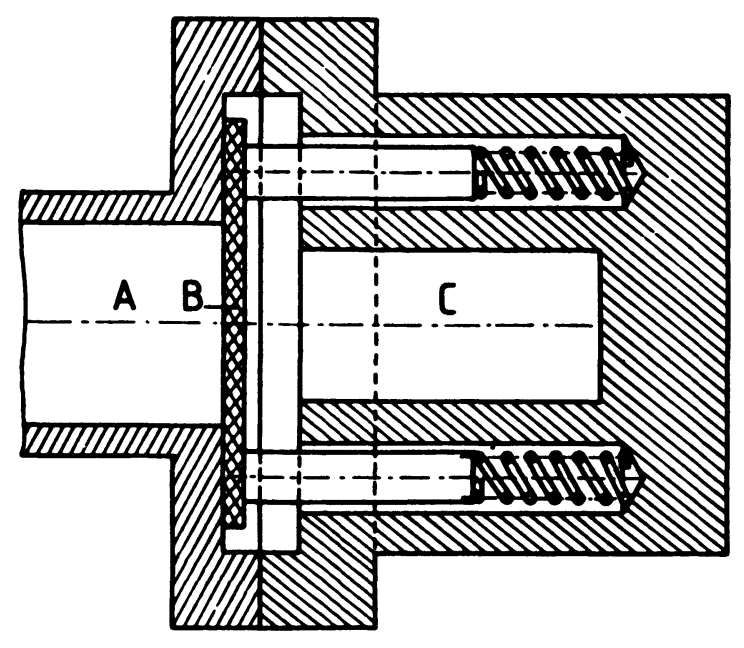

Fig. 2. - Fixing of the sample; A : rectangular waveguide; B : sample; C : cut-off circular waveguide.

4. Experimental results. - The treatments presented here were carried out with relatively low microwave powers (about $500 \mathrm{~W}$ ), which were nevertheless sufficient for feasibility measurements. In the current state of the investigation, we were not concerned with the behaviour of the cavity at high electric fields. All the samples employed consisted of silicon implanted with boron or arsenic under $200 \mathrm{kV}$ with a dose of $5 \times 10^{15} \mathrm{~cm}^{-2}$. We give, in figure 3 , as an example, the results of the annealing of an As implanted sample. After annealing under illumination, the impurity profile is not substantially altered, but recrystallization occurs as shown by the collapse of the square resistance of the annealed sample. Measurements of the latter showed that with pulses of $500 \mathrm{~W}$ power, or $1.25 \mathrm{~kW} . \mathrm{cm}^{-2}$, acting on the sample, practically perfect annealing is obtained within $200 \mathrm{~ms}$ (Fig. 4). This figure shows that over practically $5 \mathrm{~mm}$ we obtained a square resistance comparable to that obtained by standard thermal annealing. The sudden rise in the square resistance at the ends of the sample is essentially due to its thermal contact with the cavity walls (Fig. 2).

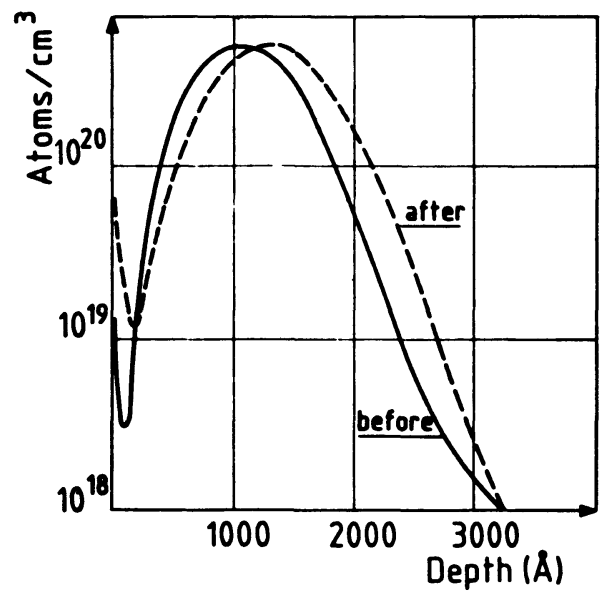

Fig. 3. - Arsenic profile (obtained by SIMS) before and after pulsed annealing by microwave energy and with illumination of the sample. Implantation dose : $5 \times 10^{15} \mathrm{~cm}^{-2}$ under $200 \mathrm{kV}$. 


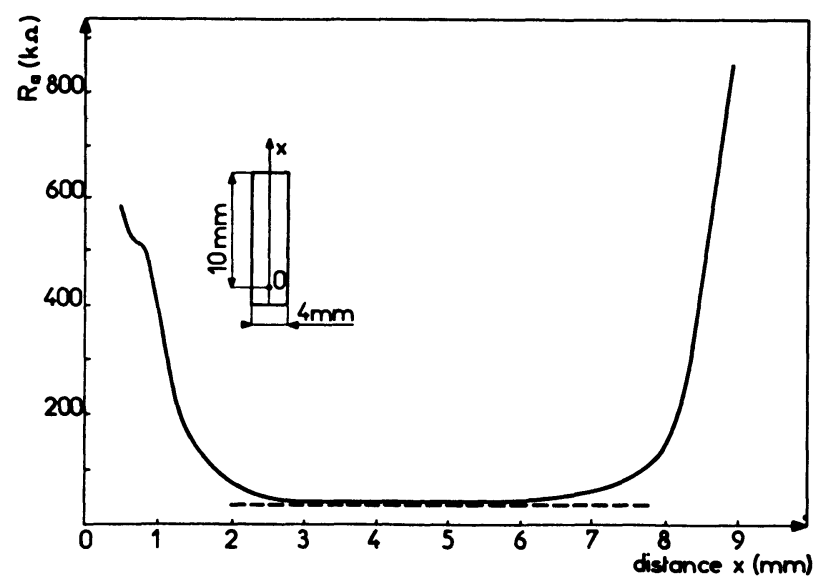

Fig. 4. - Square resistance in $X$ direction of the Si sample implanted by As : - after microwave annealing ; -..-.- after thermal (classical) annealing.

5. Conclusion. - We have demonstrated the possibility of annealing implanted silicon layers by pulsed microwave energy, provided the sample is illuminated. The role of the illumination is to initiate the absorption of microwave power; indeed the penetration depth of the light is of the order of the estimated diffusion length of free photogenerated carriers in the surface region of the semiconductor sample. So a " surface " sheet of a few $\mu \mathrm{m}$ presents, under illumination, a conductivity which is sufficient to lead to an initial absorption of the microwave energy into the same sheet. Besides the heat diffusivity is such that within a few ms the semiconductor sample reaches practically a uniform temperature along its thickness. Consequently it can be assumed that the annealing conditions do not depend on the depth (evidently for a given sample thickness).

These results demonstrate the feasibility of the method that we are now trying to refine from the technical standpoint, including higher powers, larger samples, and the thermal contact with the cavity.

The annealing process proposed may be used advantageously in the fabrication of cheap solar cells, or in various technological stages in the manufacture of Integrated Circuits.

\section{References}

[1] Kachurin, G. A., Pridachin, N. B. et Smirnov, L. S., Sov. Phys. Semicond. 9 (1975) 946.

[2] Vitali, G., Bertolotti, M. et Rimini, E., Phys. Lett. A3 (1977) 351.

[3] Foti, G., Rimini, E., Vitali, G. et Bertolotti, M., Appl. Phys. Lett. 14 (1977) 189.

[4] GAT, A., CW Laser Annealing of Ion-Implanted Single-Crystal Silicon (Edition : Coherent, Center for Laser Annealing, U.S.A.) 1979.

[5] Gibbons, J. F., Hess, L. D. et Sigmon, T. W., Laser and Electron Beam Solid Interactions and Materials Processing (North-Holland ed., N. York) 1981.

[6] (a) Cohen, R. L., Williams, J. S., Feldman, L. C. et West, K. W., Appl. Phys. Lett. 33 (1978) 759.

(b) Powell, R. A., YeP, T. O. et Fulks, R. T., Appl. Phys. Lett. 39 (1981) 150.

[7] Fulks, R. T., Russo, C. J., Hanley, P. R. et Kamins, T. J., submitted for publication in Appl. Phys. Lett., May 1981.

[8] Cohen, J., Kamarinos, G., Chenevier, P., CNRS patent 29/9/1981, № 81-18656.

[9] BOREL, G., Recuit laser de silicium implanté arsenic. Rapport EFCIS ; Direction Recherche et Développement, Service VLSI, 19 juin 1981. 